\title{
OKVIRNI MODEL MJERENJA KVALITETE PROGRAMSKE POTPORE VOĐENJU EVIDENCIJA ZAŠTITE NA RADU
}

UDK 331.45:007.5

PRIMLJENO: 16.9 .2020 .

PRIHVAĆENO: 15.3 .2021

Ovo djelo je dano na korištenje pod Creative Commons Attribution 4.0 International License

SAŽETAK: Računalna podrška vođenju evidencija zaštite na radu postala je danas nužnost i preduvjet kvalitetnog upravljanja ovim važnim i vrlo složenim područjem. U skladu s time, na hrvatskom tržištu se javlja sve veći broj programskih rješenja za potporu vođenju evidencija zaštite na radu. Funkcionalnost ovih programa i formati zapisa u Republici Hrvatskoj nisu u potpunosti propisani niti postoji službeni postupak certifikacije. U cilju utvrđivanja kvalitete ovih programskih rješenja na osnovi iskustva i zadovoljstva korisnika autori su oblikovali okvirni mjerni model organiziran u pet mjernih kategorija koje obuhvaćaju procjenu sadržaja, funkcionalne kakvoće, utilizaciju po mogućnostima, sigurnost i aktualnost podataka te ergonomiju same programske potpore. Istraživanje je provedeno online putem elektroničkog upitnika. Provedena je analiza podataka te pouzdanosti i valjanosti upitnika. Za dva programska rješenja prikupljen je relevantan broj ispitanika. U oba slučaja ukupne ocjene kvalitete ne razlikuju se značajno, ali upućuju na vrlo veliki prostor za daljnji napredak funkcionalne kvalitete.

Ključne riječi: zaštita na radu, računalna podrška, mjerni model, funkcionalna kvaliteta, programska ergonomija

\section{UVOD}

Računalna podrška vođenju evidencija zaštite na radu (ZNR) danas je nužnost i preduvjet kvalitetnom upravljanju ovim važnim, širokim i složenim područjem. U skladu s time, na hrvatskom tržištu javlja se sve veći broj programskih rješenja kao potpora vođenju evidencija zaštite na radu. Oblik i način vođenja evidencija nije u potpunosti zakonski definiran, niti trenutno postoji neka vrsta industrijske inicijative koja bi propisala ili barem, na temelju dogovora između proizvođača programske potpore, odredila neke normative u ovom području. Već površna analiza stanja unutar hrvatskih tvrtki ukazuje na različitosti u pristupu primjeni programske podrške vođenju eviden-

*Tomislav Jajetić, struč. spec. ing. sec., (tomislav.jajetic@posta.hr), Hrvatska pošta d.d., Poštanska ulica 9, 10410 Velika Gorica, dr. sc. Damir Kralj, prof. v. š., (damir.kralj@vuka.hr), Veleučilište u Karlovcu, Odjel sigurnosti i zaštite, Trg J. J. Strossmayera 9, 47000 Karlovac. cija ZNR. Jedan dio poslodavaca još se odlučuje za „papirnati“ oblik vođenja evidencija. Nažalost, iako danas postoje specijalizirani računalni programi čije cijena je vrlo prihvatljiva, mnogobrojne tvrtke "papirnati” način vođenja evidencija nadopunjavaju upotrebom raznih Excel tablica, opravdavajući isto niskim troškovima. Često je slučaj da tek nakon inspekcijskog nadzora Državnog Inspektorata, kada se utvrdi da je prošao rok važenja nekog dokumenta, poslodavci počinju shvaćati svoju odgovornost. Takav trenutak u poslovanju važan je za uviđanje neophodnog ulaganja u nove tehnologije kao i radnike. Trošak nastupa i u slučajevima kada se nabavi programska podrška koja se ne primjenjuje bilo zbog neadekvatne instalacije na računalu ili zbog nezadovoljstva krajnjih korisnika.

Ako se analizira stanje u svjetskim razmjerima Međunarodna organizacija rada (eng. International Labour Organization, ILO) je u povodu 
Međunarodnog dana sigurnosti i zdravlja na poslu, 28. travnja 2017. godine, predstavila ideju prikupljanja i obrade podataka u vezi sa ZNR na međunarodnom planu (ILO, 2017.). Na području Europske unije (EU), Hrvatska je kroz EU projekte IPA2007 i IPA 2012 (Uredbe Vijeća EU: 1085/2006, 718/2007) dobila zadaću oblikovanja nacionalne infrastrukture u ZNR. Ova zadaća praktično znači izgradnju središnjeg informacijskog sustava koji će obuhvaćati sve jedinstvene nomenklature i prikupljati sve relevantne podatke u području ZNR u Republici Hrvatskoj $(\mathrm{RH})$ te na taj način omogućiti bržu i učinkovitiju prevenciju od potencijalnih rizika kao i bolju zaštitu zdravlja i sposobnosti radnika, a kroz te aktivnosti i smanjenje troškova proizvodnje. Na tržištu prisutne aplikacije za vođenje evidencija ZNR postat će, u tom kontekstu, klijentske aplikacije koje će prikupljati podatke na terenu, obavljati njihovu primarnu obradu i puniti središnji nacionalni repozitorij ovih podataka smješten unutar jedinstvenog informacijskog sustava ZNR u RH. Ovo je bio još jedan razlog koji nas je ponukao da se pristupi razvoju mjernog modela i alata za mjerenje kakvoće aplikacija za vođenje evidencija ZNR dostupnih na hrvatskom tržištu. Na tržištu je trenutno dostupno desetak aplikacija ovog tipa koje su s tehnološkotehničkog gledišta koncipirane na razne načine: globalne mrežne aplikacije (cloud i web), preko lokalno mrežnih aplikacija pa do lokalno instaliranih jednokorisničkih aplikacija. Osim ovih razlika, predmetne aplikacije ne pokrivaju jednaki raspon funkcionalnosti (broj mogućnosti i evidencija). Često se na raznim stručnim skupovima i radionicama čuje kako se pojedini proizvođači žale da njihova aplikacija ima veće mogućnosti od nekih konkurentskih, ali korisnici ih ne koriste pa ih stoga funkcionalno izjednačavaju. To je autore ponukalo da pored same kakvoće funkcionalnosti, uvedu i kategoriju za tzv. utilizaciju tj. stupanj korištenja pojedinih mogućnosti (Vučinić, 2008.).

Dakle, ovaj rad za cilj ima odrediti bitne čimbenike kvalitete, oblikovati mjerni model za procjenu kvalitete koji sistematizira ove čimbenike te primijeniti taj model u cilju izmjere kvalitete na tržištu dostupne programske potpore. Osnovna pretpostavka bila je da polazeći od pretpostavke da se psihometrijskim mjerenjem zadovoljstva pojedinaca tj. stručnjaka zaštite na radu, koji su korisnici nekog od na tržištu dostupnih program- skih rješenja za vođenje evidencija zaštite na radu, može procijeniti kvaliteta predmetne programske podrške.

\section{METODOLOGIJA}

Za potrebe provođenja eksperimentalnog rada definirana je sljedeća metodologija:

- teoretsko istraživanje i prikupljanje praktičnih iskustava

- oblikovanje strukture i kategorija mjernog modela

- oblikovanje čestica koje opisuju svaku od pojedinih kategorija

- oblikovanje modela mjernog alata (upitnika) za provođenje mjerenja

- izbor anketnog sustava i oblikovanje elektroničkog upitnika

- priprema i čišćenje prikupljenih rezultata

- statistička analiza prikupljenih podataka

- osnovna validacija mjernog modela

- analiza i oblikovanje zaključaka o mjerenom području.

\section{Oblikovanje mjernog modela i upitnika}

Polazeći od pretpostavke da se psihometrijskim mjerenjem (Urbina, 2004.) zadovoljstva pojedinaca tj. stručnjaka zaštite na radu, koji su korisnici nekog od na tržištu dostupnih programskih rješenja za vođenje evidencija iz područja ZNR, može procijeniti kvaliteta predmetne programske podrške, a na temelju prethodne teorijske analize stanja, oblikovan je okvirni model mjerenja (Kline, 1998.) koji se sastoji od pet kategorija:

- Opći podaci

- Domenska kategorija - kakvoća (A)

- Domenska kategorija - utilizacija (B)

- Sigurnost i aktualnost podataka (C)

- Ergonomska kategorija (D).

Opći podaci: sadrže devet pitanja te obuhvaćaju podatke kao što su: dob, spol i staž korisnika, naziv radnog mjesta i općenito o programskoj podršci koju koristi. Ova kategorija daje opis ispitne populacije. 
Kakvoća: domenska je kategorija (iz stručnog područja, tj. ZNR) i kroz 16 pitanja mjeri zadovoljstvo korisnika (a time mjeri posredno i kvalitetu) pojedinim funkcionalnostima ugrađenim u programsko rješenje.

Utilizacija: domenska kategorija koja u 17 pitanja mjeri stupanj korištenja u prethodnoj kategoriji ocijenjenih funkcionalnosti u praksi.

Sigurnost i aktualnost podataka: kroz šest pitanja obuhvaća sve aspekte sigurnosti i aktualizacije podataka i nomenklature te obuhvaća zaštitu od neovlaštenog pristupa podacima, upravljanje ovlastima i ulogama korisnika, kao i primjenu metoda zaštite od gubitka podataka. Potreba poznavanja stupnja sigurnosti, kao i aktualnosti postojećih podataka proizlazi iz odredbi Zakona o sigurnosti podataka.

Ergonomska kategorija: kroz 10 pitanja bavi se programskom ergonomijom pa u tom smislu upotrebljivošću programske podrške izraženom kroz zadovoljstvo korisnika te obuhvaća ocjenu lakoće i intuitivnost uporabe korisničkog sučelja, mogućnosti prilagodbe korisničkog sučelja zahtjevima korisnika, mogućnosti daljinske podrške i unapređenje verzije programske potpore od strane proizvođača (isporučitelja), mogućnosti oblikovanja prikaza poruka i osobnih podsjetnika stručnjaka ovisno o kontekstu, ocjenu kakvoće sustava pomoći, kakvoću korisničkih uputa, kao i sveukupno zadovoljstvo korisnika uporabom programske potpore.

Detaljan prikaz čestica koje čine pojedine kategorije bit će dan u prikazu rezultata istraživanja.

\section{Oblikovanje upitnika i provođenje ankete}

$\cup$ skladu s definiranim mjernim modelom sastavljen je upitnik u kojem su ispitanici trebali izraziti svoje stajalište o tome koliko je pojedina navedena funkcionalnost primijenjena i/ili izvedena u programskoj potpori koju koriste u svojem svakodnevnom radu. Za mjernu ljestvicu autori su uzeli pet-stupanjsku Likertovu ljestvicu: 1-Uopće nije primijenjeno ili neupotrebljivo; 2-Loše primijenjeno, 3-Osrednje primijenjeno; 4-Uspješno primijenjeno i 5-Vrlo uspješno primijenjeno. Razmak između odgovora smatra se ekvidistantnim. Pojedinim kategorijama odgovora pridruženi su brojevi (bodovi), stajalište ispitanika izražava se zbrojem bodova na temelju odgovora koje je ispitanik odabrao. Zbog toga se Likertova ljestvica naziva još i sumativna ljestvica. Što je taj zbroj veći, ispitanikovo stajališste prema objektu (kategoriji) je pozitivnije (Grassi et al., 2007., Reynaldo, Santos, 1999., Urbina, 2004.).

Anketni upitnik sastavljen je korištenjem mrežne usluge Google Forms (hrv. Google obrasci); (Jajetić, Kralj, 2020.). Detalj zaslonskog obrasca upitnika prikazan je na slici 1. Poveznica za pristup elektroničkom anketnom obrascu, zajedno s prikladnim motivacijskim pismom, distribuirana je putem elektroničke pošte na adrese 241 osobe u Republici Hrvatskoj za koje se smatralo da se bave u užem i širem smislu zaštitom zdravlja i sigurnošću radnika. Razdoblje mjerenja, odnosno vrijeme dostupnosti anketnog obrasca, trajalo je od 1.9.2019. do 31.12.2019. godine. S obzirom na važeći Zakon o zaštiti osobnih podataka (GDPR), kontakte za slanje anketnog upitnika autori su sakupili iz javno dostupnih časopisa i zbornika radova, a koji su naravno bili naslonjeni na tematiku zaštite na radu, odnosno sigurnost i zdravlje radnika na radnom mjestu.

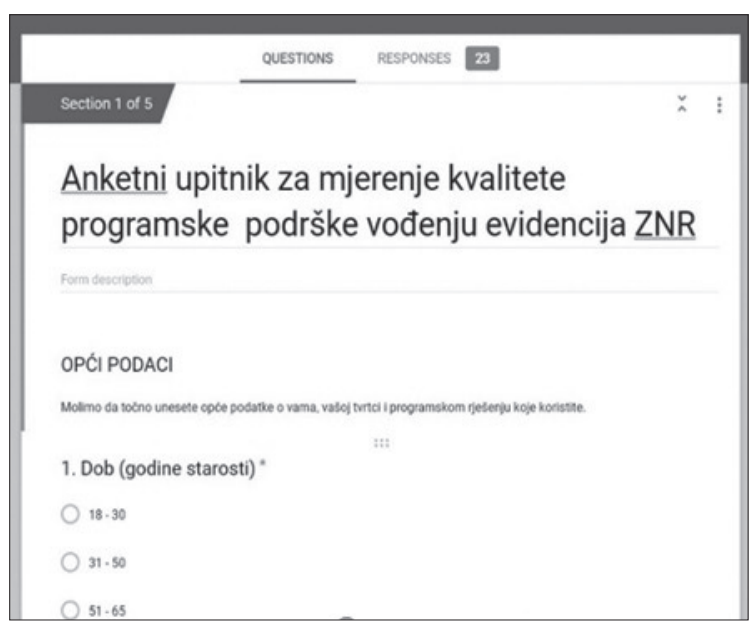

Slika 1. Detalj zaslonskog obrasca upitnika

Figure 1. Detail of the screen form of the questionnaire

\section{Statističke metode i testovi}

Deskriptivna statistika služila je za prikaz ispitanika s obzirom na dob, spol, broj zaposlenih u tvrtki i programsko rješenje koje se koristi za provedbu rada. Za ispravan izbor metoda statističkih testiranja, ključno je analizirati svojstva raspo- 
djele prikupljenih rezultata. Primjenom ShapiroWilk testa analizirana je normalnost raspodjele mjerene populacije. Veličina uzorka značajno utječe na normalnost raspodjele populacije, gdje se vrlo često opaža nenormalna raspodjela kod malih uzoraka, što je rezultat neadekvatne procjene disperzije podataka gdje raspodjela frekvencije ne rezultira normalnom krivuljom. Primjenom Shapiro-Wilk testa analizirana je normalnost raspodjele podataka. S obzirom na očekivanu veličinu uzorka i nenormalnu raspodjelu, autori su predvidjeli neparametrijske statističke testove za utvrđivanje statistički značajnih razlika raspodjele s obzirom na nezavisne varijable (Mann-Whitney $\mathrm{U}$ test, Kruskal-Wallis $\mathrm{H}$ test). Vrijednosti $\mathrm{p}<0,05$ smatrane su statistički značajnima, vjerojatnost slučajne pogreške iznosi $5 \%$. Za statističku analizu korišten je software SPSS (verzija 25.1, SPSS, Chicago); (Eterović, Kardum, 2010., Pallant, 2007., Zar, 2010.).

Pouzdanost mjerne ljestvice analizirana je Cronbach alpha koeficijentom (Cronbach et al., 1972.). Iz razloga što su ljudi, odnosno čovjek kao takav, najnepouzdaniji mjerni pretvornik, autori su morali provjeriti koliko je njihov alat pouzdan. Najjednostavniji je izračun ovog koeficijenta koji mora bit jednak ili veći 0,7. Što se tiče kriterija pouzdanosti mjernih ljestvica, Kline (1998.) navodi da ako koeficijent pouzdanosti poprimi vrijednost oko 0,9, pouzdanost se može smatrati izvrsnom. No, neki puta se iznosi Cronbach alfa i nešto manji od 0,7 mogu smatrati zadovoljavajućim ako se radi o ljestvicama s manjim brojem čestica (s povećanjem broja čestica, bilježi se i porast koeficijenta pouzdanosti) ili pak, s druge strane, ako se radi o vrlo nehomogenoj ispitnoj populaciji s kojom nije rađena nikakva priprema za provođenje testiranja (Kline, 1998., Pallant, 2007., Urbina, 2004.).

\section{REZULTATI}

Od ukupno 241 upućenih zamolbi za ispunjavanje upitnika 27 (11,20\%) elektroničkih adresa bilo je nevažeće. Od 214 kontaktiranih pristupnika, njih 47 (21,96\% populacije) ispunilo je anketni upitnik. Nakon obrade i postupka čišćenja pristiglih odgovora, ostalo je 34 pristupnika $(72,34 \%$ od prikupljenih slučajeva; $15,89 \%$ od ukupno kontaktirane populacije) tj. slučajeva nad kojima je provedena daljnja statistička obrada. Čišćenje je provedeno potpunim uklanjanjem slučajeva koji su nezaposleni ili ne koriste niti jednu aplikaciju (4); koriste aplikacije drugih proizvođača, ali ne čine relevantan broj korisnika za daljnju obradu (Burin - 1, SUZ - 2, EVIZ - 1, Fininfo - 1) ili koriste neke univerzalne alate kao što je MS Excel (4), što se ne smatra specijaliziranom programskom podrškom za vođenje evidencija ZNR. Za programska rješenja WebZNR (Linija koda, 2020.) i Sinarm (webIT, 2020.) prikupljen je relevantan broj uzoraka koji su u nastavku bili podvrgnuti daljnjoj obradi i statističkoj analizi.

\section{Deskriptivna statistika ispitne populacije}

Nad općim podacima o ispitnoj populaciji provedena je osnovna deskriptivna statistika. Raspodjela ispitanika s obzirom na dob, spol, broj zaposlenih u tvrtki i programsko rješenje koje se koristi za provedbu rada prikazana je u Tablici 1, dok je raspodjela načina na koji su ispitanici saznali za pojedino programsko rješenje, koje koriste u svojem radu, prikazana u Tablici 2 .

\section{Tablica 1. Opći podaci ispitanika}

Table 1. General data on respondents

\begin{tabular}{||l|c||}
\hline \multicolumn{1}{||c|}{ Parametri } & Ukupan broj ispitanika n = 34 \\
\hline Spol, n (\%) & $7(21)$ \\
\hline Ženski & $27(79)$ \\
\hline Muški & $5(15)$ \\
\hline Dob (godine), n (\%) & $18(53)$ \\
\hline $18-30$ & $11(32)$ \\
\hline $31-50$ & $6(18)$ \\
\hline $51-65$ & $1(3)$ \\
\hline Poslovni subjekt - broj zaposlenih, n (\%) \\
\hline$<10$ & $27(79)$ \\
\hline $50-250$ & $7(21)$ \\
\hline$>250$ & $27(79)$ \\
\hline Programsko rješenje, n (\%) & \\
\hline Sinarm & \\
\hline WebZNR & \\
\hline
\end{tabular}


Tablica 2. Način saznavanja za aplikaciju

Table 2. The way of found out about the application

\begin{tabular}{||l|c||}
\hline \multicolumn{1}{|c||}{ Način } & n (\%) \\
\hline Na stručnim skupovima & $2(6)$ \\
\hline $\begin{array}{l}\text { Od ovlaštene tvrtke koja obavlja } \\
\text { ispitivanja ili osposobljavanja }\end{array}$ & $11(32)$ \\
\hline Od prodajnog predstavnika aplikacije & $11(32)$ \\
\hline Preko poznanika & $7(21)$ \\
\hline Web stranice i društveni mediji & $3(9)$ \\
\hline
\end{tabular}

Zadnje pitanje u kategoriji opći podaci odnosilo se na korištenje programskog rješenja u kombinaciji s nekim drugim mogućnostima. Rezultati su prikazani na slici 2 . Tako je $18(52,94 \%)$ ispitanika odgovorilo da se dodatno koristi i Excel tablicama ili sličnim tabličnim kalkulatorom, 13 $(38,24 \%)$ ih isključivo koristi programsko rješenje (WebZNR/Sinarm), 2 (5,88 \%) ispitanika sve evidencije vodi još i ručno na papiru, dok se 1 (2,94 $\%$ ) ispitanik pored glavne, koristi i nekom sličnom aplikacijom drugog proizvođača.

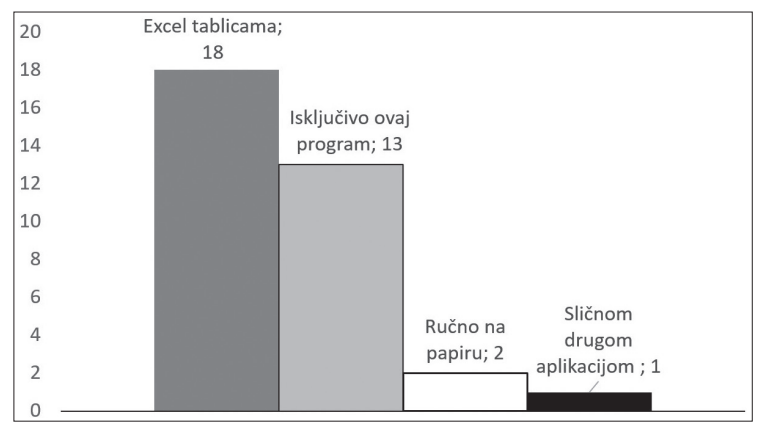

Slika 2. Korištenje drugih programa i pomagala

Figure 2. Use of other software and aids

\section{Rezultati po mjernim kategorijama}

Prema deskriptivnoj statističkoj analizi ispitne populacije pristupilo se obradi prikupljenih rezultata grupiranih po mjernim kategorijama. Kako je već u metodologiji istaknuto, izbor statističkih testova znatno ovisi o svojstvima i raspodjeli prikupljenih rezultata po česticama pojedine kategorije (tzv. konstruktima). Kako je ukupan broj prikupljenih slučajeva manji od 50, za test normalnosti raspodjele uzoraka izabran je Shapiro-Wilk test, koji za razliku od često korištenog Kolmogorov-Smirnov testa, pokazuje veću osjetljivost u slučaju malih uzoraka. Interpretacijom rezultata Shapiro-Wilk testa zabilježene su vrijednosti $p<0,05$ koje su statistički značajne, čime se H0 hipoteza: distribucija podataka je normalna, odbacuje i distribucija podataka je okarakterizirana kao nenormalna. Mali uzorak, ordinalne varijable i nenormalna raspodjela rezultata upućuju na daljnji izbor neparametrijskih statističkih testova. Kako su autori po pregledu prikupljenih rezultata dobili samo dvije aplikacije s relevantnim brojem slučajeva, za daljnju usporedbu i testiranje na statistički značajne razlike u raspodjeli ocjena s obzirom na nezavisnu varijablu "Naziv aplikacije", korišten je Mann-Whitney $U$ test. $U$ slučaju da su autori imali više aplikacija s relevantnim brojem slučajeva u uzorku, koristili bi se Kruskal-Wallis $\mathrm{H}$ testom (Eterović, Kardum, 2010., Zar, 2010.).

Prosječne ocjene za sve četiri glavne mjerne kategorije prikazane su u tablicama 3-6. Ocjene su izražene za svaku česticu pojedine kategorije za obje mjerene aplikacije $s$ izraženom $p$ vrijednošću statističke različitosti raspodjele ocjena te $s$ korigiranim Cronbach alfa koeficijentom, tj. vrijednošću ovog koeficijenta za cijeli konstrukt kad se izbaci predmetna čestica (bez samokorelacije). 
Tablica 3. Prosječne ocjene za "Domensku kategoriju - kakvoća"

Table 3. Average ratings for the "Domain category quality "

\begin{tabular}{|c|c|c|c|c|}
\hline Čest. & Sinarm & WebZNR & $\mathbf{p}$ & Kor. C. $\alpha$ \\
\hline \multirow[t]{2}{*}{$\mathrm{A} 1$} & \multicolumn{4}{|c|}{$\begin{array}{l}\text { Evidencija podataka o radnicima i } \\
\text { osposobljavanju }\end{array}$} \\
\hline & 4,00 & 3,85 & 0,465 & 0,909 \\
\hline \multirow{2}{*}{$\mathrm{A} 2$} & \multicolumn{4}{|c|}{$\begin{array}{l}\text { Evidencija radne opreme i osobnih zaštitnih } \\
\text { sredstava }\end{array}$} \\
\hline & 3,57 & 3,63 & 0,622 & 0,905 \\
\hline \multirow[t]{2}{*}{ A3 } & \multicolumn{4}{|c|}{$\begin{array}{l}\text { Evidencija sredstava rada (objekata, ispitivanja } \\
\text { i radnog okoliša) }\end{array}$} \\
\hline & 3,71 & 3,56 & 0,790 & 0,901 \\
\hline \multirow[t]{2}{*}{ A4 } & \multicolumn{4}{|c|}{$\begin{array}{l}\text { Popunjavanje liječničkih uputnica i prijava } \\
\text { ozljeda na radu }\end{array}$} \\
\hline & 3,71 & 3,74 & 0,650 & 0,907 \\
\hline \multirow[t]{2}{*}{ A5 } & \multicolumn{4}{|c|}{$\begin{array}{l}\text { Pregled i ažuriranje rokova za ispitivanja, } \\
\text { obnavljanje uvjerenja i zaštitnih sredstva }\end{array}$} \\
\hline & 3,29 & 3,41 & 0,563 & 0,905 \\
\hline \multirow{2}{*}{ A6 } & \multicolumn{4}{|c|}{ Izrada procjene rizika } \\
\hline & 2,71 & 2,63 & 0,824 & 0,896 \\
\hline \multirow[t]{2}{*}{ A7 } & \multicolumn{4}{|c|}{$\begin{array}{l}\text { Digitalna arhiva (samostalno učitavanje } \\
\text { skeniranih dokumenata) }\end{array}$} \\
\hline & 3,14 & 3,44 & 0,327 & 0,907 \\
\hline \multirow[t]{2}{*}{ A8 } & \multicolumn{4}{|c|}{$\begin{array}{l}\text { Modul za osposobljavanje radnika } \\
\text { (e-learning) }\end{array}$} \\
\hline & 2,43 & 2,30 & 0,737 & 0,895 \\
\hline \multirow{2}{*}{ A9 } & \multicolumn{4}{|c|}{ Rad s mobilnih uređaja } \\
\hline & 2,00 & 1,96 & 0,798 & 0,901 \\
\hline
\end{tabular}

\begin{tabular}{|c|c|c|c|c|}
\hline \multirow[t]{2}{*}{ A10 } & \multicolumn{4}{|c|}{$\begin{array}{l}\text { Automatsko učitavanje podataka (zapisnik, } \\
\text { uvjerenje, radni nalog...itd.) iz ovlaštene tvrtke } \\
\text { koja obavlja ispitivanje ili održavanje }\end{array}$} \\
\hline & 2,57 & 2,07 & 0,387 & 0,896 \\
\hline \multirow[t]{2}{*}{ A11 } & \multicolumn{4}{|c|}{$\begin{array}{l}\text { Mogućnost izrade upitnika koje mogu } \\
\text { popunjavati vaši radnici i rukovoditelji, a vi } \\
\text { prikupljati rezultate (tzv. kontrolne liste). }\end{array}$} \\
\hline & 2,71 & 1,89 & 0,114 & 0,892 \\
\hline \multirow{2}{*}{ A12 } & \multicolumn{4}{|c|}{ Praćenje stanja skladišta zaštitne opreme } \\
\hline & 3,43 & 2,30 & 0,050 & 0,895 \\
\hline \multirow[t]{2}{*}{ A13 } & \multicolumn{4}{|c|}{$\begin{array}{l}\text { Praćenje i planiranje troškova (za sva } \\
\text { ispitivanja i liječničke preglede) }\end{array}$} \\
\hline & 3,29 & 2,26 & $0,043^{*}$ & 0,900 \\
\hline \multirow[t]{2}{*}{ A14 } & \multicolumn{4}{|c|}{$\begin{array}{l}\text { Prikupljanje i obrada senzorskih podataka } \\
\text { (npr. detekcija da li je vatrogasni aparat na } \\
\text { svojem mjestu) }\end{array}$} \\
\hline & 2,71 & 2,11 & 0,250 & 0,900 \\
\hline \multirow[t]{2}{*}{ A15 } & \multicolumn{4}{|c|}{$\begin{array}{l}\text { Izravna prijava ozljede na radu iz aplikacije } \\
\text { bez slanja papira (prema liječniku i HZZO-u) }\end{array}$} \\
\hline & 2,00 & 1,81 & 0,429 & 0,901 \\
\hline \multirow[t]{2}{*}{ A16 } & \multicolumn{4}{|c|}{$\begin{array}{l}\text { Vođenje specifičnih evidencija iz domene } \\
\text { zaštite od požara (periodična ispitivanja i } \\
\text { redovna održavanja - servisi) }\end{array}$} \\
\hline & 3,29 & 3,22 & 0,889 & 0,905 \\
\hline
\end{tabular}

*statistički značajna razlika

U Tablici 3 vidi se da je Cronbach alfa koeficijent za cijelu mjernu ljestvicu $>0,7$ i iznosi 0,907 a korigirani koeficijenti Cronbach alfa u rasponu su 0,892-0,909 što ukazuje na to da sve čestice pridonose ukupnoj ocjeni konstrukta tj. "Domenskoj kategoriji - kakvoći" i potvrđuju konstruktnu valjanost ovog segmenta mjernog modela. Vidi se da je za česticu A13 p=0,043 što je manje od 0,5, pri čemu to znači da se raspodjele ocjena za predmetne aplikacije statistički značajno razlikuju. 
Tablica 4. Prosječne ocjene za "Domensku kategoriju - utilizacija"

Table 4. Average ratings for the "Domain category utilization"

\begin{tabular}{|c|c|c|c|c|}
\hline Čest. & Sinarm & WebZNR & $p$ & Kor. C. $\alpha$ \\
\hline \multirow[t]{2}{*}{ B1 } & \multicolumn{4}{|c|}{$\begin{array}{l}\text { Koliko često uopće koristite predmetnu } \\
\text { programsku podršku? }\end{array}$} \\
\hline & 3,43 & 4,52 & 0,053 & 0,901 \\
\hline \multirow[t]{2}{*}{ B2 } & \multicolumn{4}{|c|}{$\begin{array}{l}\text { Koliko često koristite evidenciju podataka o } \\
\text { radnicima i osposobljavanju? }\end{array}$} \\
\hline & 3,43 & 4,22 & 0,196 & 0,896 \\
\hline \multirow[t]{2}{*}{ B3 } & \multicolumn{4}{|c|}{$\begin{array}{l}\text { Koliko često koristite evidenciju radne opreme } \\
\text { i osobnih zaštitnih sredstava? }\end{array}$} \\
\hline & 2,57 & 3,37 & 0,266 & 0,894 \\
\hline \multirow[t]{2}{*}{ B4 } & \multicolumn{4}{|c|}{$\begin{array}{l}\text { Koliko često koristite evidenciju sredstava rada } \\
\text { (objekata ispitivanja i radnog okoliša)? }\end{array}$} \\
\hline & 2,71 & 3,44 & 0,315 & 0,890 \\
\hline \multirow[t]{2}{*}{ B5 } & \multicolumn{4}{|c|}{$\begin{array}{l}\text { Koliko često popunjavate liječničke uputnice i } \\
\text { prijave o ozljedi na radu? }\end{array}$} \\
\hline & 2,57 & 2,96 & 0,570 & 0,896 \\
\hline \multirow[t]{2}{*}{ B6 } & \multicolumn{4}{|c|}{$\begin{array}{l}\text { Koliko često pregledavate rokove za } \\
\text { ispitivanja, obnavljanje uvjerenja i zaštitnih } \\
\text { sredstava? }\end{array}$} \\
\hline & 2,71 & 3,63 & 0,141 & 0,894 \\
\hline \multirow[t]{2}{*}{ B7 } & \multicolumn{4}{|c|}{$\begin{array}{l}\text { Koliko često evidentirate nastale promjene u } \\
\text { procjeni rizika? }\end{array}$} \\
\hline & 1,86 & 1,93 & 0,649 & 0,895 \\
\hline \multirow[t]{2}{*}{ B8 } & \multicolumn{4}{|c|}{$\begin{array}{l}\text { Koliko često samostalno učitavate skenirane } \\
\text { dokumente u programsko rješenje (bazu } \\
\text { ZNR)? }\end{array}$} \\
\hline & 2,00 & 3,26 & 0,084 & 0,898 \\
\hline \multirow[t]{2}{*}{ B9 } & \multicolumn{4}{|c|}{$\begin{array}{l}\text { Koliko često se služite modulom za } \\
\text { osposobljavanje radnika (e-learning)? }\end{array}$} \\
\hline & 1,14 & 1,41 & 0,587 & 0,905 \\
\hline \multirow[t]{2}{*}{ B10 } & \multicolumn{4}{|c|}{$\begin{array}{l}\text { Koliko često pristupate programskom rješenju } \\
\text { (aplikaciji) s mobilnog uređaja? }\end{array}$} \\
\hline & 1,14 & 1,70 & 0,676 & 0,898 \\
\hline \multirow[t]{2}{*}{ B11 } & \multicolumn{4}{|c|}{$\begin{array}{l}\text { Koliko često koristite automatsko učitavanje } \\
\text { podataka (zapisnika, uvjerenja) iz ovlaštenih } \\
\text { tvrtki koje obavljaju ispitivanje ili održavanje? }\end{array}$} \\
\hline & 1,00 & 1,44 & 0,226 & 0,904 \\
\hline \multirow[t]{2}{*}{ B12 } & \multicolumn{4}{|c|}{$\begin{array}{l}\text { Koliko često koristite mogućnost izrade } \\
\text { upitnika koje mogu popunjavati radnici i } \\
\text { rukovoditelji, a vi prikupljati rezultate (tzv. } \\
\text { kontrolne liste)? }\end{array}$} \\
\hline & 1,14 & 1,52 & 0,567 & 0,897 \\
\hline
\end{tabular}

\begin{tabular}{|c|c|c|c|c|}
\hline \multirow[t]{2}{*}{ B13 } & \multicolumn{4}{|c|}{$\begin{array}{l}\text { Koliko često koristite praćenje stanja na } \\
\text { skladištu zaštitne opreme? }\end{array}$} \\
\hline & 2,00 & 1,41 & 0,084 & 0,900 \\
\hline \multirow[t]{2}{*}{ B14 } & \multicolumn{4}{|c|}{$\begin{array}{l}\text { Koliko često koristite praćenje i planiranje } \\
\text { troškova (za sva ispitivanja i liječničke } \\
\text { preglede)? }\end{array}$} \\
\hline & 2,00 & 1,48 & 0,133 & 0,900 \\
\hline \multirow[t]{2}{*}{ B15 } & \multicolumn{4}{|c|}{$\begin{array}{l}\text { Koliko često koristite i pratite prikupljanje i } \\
\text { obradu senzorskih podataka (npr. detekcija da } \\
\text { li je vatrogasni aparat na svojem mjestu)? }\end{array}$} \\
\hline & 1,29 & 1,15 & 0,283 & 0,907 \\
\hline \multirow[t]{2}{*}{ B16 } & \multicolumn{4}{|c|}{$\begin{array}{l}\text { Koliko često izravno šaljete prijave o } \\
\text { ozljedama na radu iz aplikacije bez slanja } \\
\text { papira (prema liječniku i HZZO-u)? }\end{array}$} \\
\hline & 1,00 & 1,11 & 0,611 & 0,905 \\
\hline \multirow[t]{2}{*}{ B17 } & \multicolumn{4}{|c|}{$\begin{array}{l}\text { Koliko često koristite evidencije iz domene } \\
\text { zaštite od požara (periodična ispitivanja i } \\
\text { redovna održavanja - servisi)? }\end{array}$} \\
\hline & 2,29 & 2,56 & 0,343 & 0,892 \\
\hline
\end{tabular}

U Tablici 4 vidi se da je Cronbach alfa koeficijent za cijelu mjernu ljestvicu $>0,7$ i iznosi 0,904, a korigirani koeficijenti Crnobach alfa u rasponu su 0,890-0,907 što ukazuje na to da sve čestice pridonose ukupnoj ocjeni konstrukta tj. "Domenskoj kategoriji - utilizaciji" i potvrđuju konstruktnu valjanost ovog segmenta mjernog modela.

Cronbach alfa koeficijent za cijelu mjernu ljestvicu kategorije "Sigurnost i aktualnost podataka" (Tablica 5) je >0,7 i iznosi 0,744, a korigirani koeficijenti Crnobach alfa u rasponu su 0,656-0,763 što ukazuje na to da sve čestice, unatoč nešto nižoj vrijednosti koeficijenta, pridonose ukupnoj ocjeni konstrukta i potvrđuju konstruktnu valjanost ovog segmenta mjernog modela. Može se primijetiti da su iznosi korigiranih Cronbach alfa koeficijenata ovdje nešto manji, što može ukazivati na nešto manju jasnoću pitanja ispitnoj populaciji s obzirom na to da ispitna populacija nije bila prethodno pripremana (posebno u slučaju pitanja C2, C5 i C6, gdje se uklanjanjem koeficijent povećava), ali može biti posljedica relativno malog broja čestica unutar konstrukta. Za česticu C4 raspodjele ocjena se statistički značajno razlikuju $(p=0,003)$. 
Tablica 5. Prosječne ocjene za kategoriju "Sigurnost i aktualnost podataka"

Table 5. Average ratings for the category "Data security and actuality of data"

\begin{tabular}{|c|c|c|c|c|}
\hline Čest. & Sinarm & WebZNR & $\mathbf{p}$ & Kor. C. $\alpha$ \\
\hline \multirow{2}{*}{ C1 } & \multicolumn{4}{|c|}{$\begin{array}{l}\text { Po načinu instalacije vaše programsko rješenje } \\
\text { je }\end{array}$} \\
\hline & 2,57 & 3,44 & 0,066 & 0,656 \\
\hline \multirow[t]{2}{*}{$\mathrm{C} 2$} & \multicolumn{4}{|c|}{$\begin{array}{l}\text { Kontrola pristupa i uloge pojedinih korisnika } \\
\text { unutar vašeg programskog rješenja ostvarene } \\
\text { su na siguran i jednoznačan način }\end{array}$} \\
\hline & 4,00 & 3,41 & 0,083 & 0,763 \\
\hline \multirow{2}{*}{ C3 } & \multicolumn{4}{|c|}{$\begin{array}{l}\text { Na koji način i koliko često se vrši pohrana } \\
\text { unesenih podataka? }\end{array}$} \\
\hline & 3,28 & 3,15 & 0,947 & 0,666 \\
\hline \multirow[t]{2}{*}{$\mathrm{C} 4$} & \multicolumn{4}{|c|}{$\begin{array}{l}\text { Na koji način se u vaše programsko } \\
\text { rješenje unose i ažuriraju matični podaci } \\
\text { (o djelatnicima i ustroju tvrtke, odnosno } \\
\text { sinkronizacija s glavnim IS-om tvrtke)? }\end{array}$} \\
\hline & 2,43 & 3,51 & $0,003^{*}$ & 0,683 \\
\hline \multirow[t]{2}{*}{ C5 } & \multicolumn{4}{|c|}{$\begin{array}{l}\text { Na koji način se ažuriraju ključne } \\
\text { nomenklature (npr. zaštitne opreme, uređaja i } \\
\text { sustava, zakonskih odredbi) i razni obrasci? }\end{array}$} \\
\hline & 2,57 & 3,19 & 0,275 & 0,711 \\
\hline \multirow[t]{2}{*}{ C6 } & \multicolumn{4}{|c|}{$\begin{array}{l}\text { Iz dosadašnjeg radnog iskustva ovo } \\
\text { programsko rješenje može se ocijeniti vrlo } \\
\text { pouzdanim u radu }\end{array}$} \\
\hline & 4,00 & 3,74 & 0,857 & 0,742 \\
\hline
\end{tabular}

*statistički značajna razlika

U Tablici 6 vidi se da je Cronbach alfa koeficijent za cijelu mjernu ljestvicu "Ergonomske kategorije $>0,7$ i iznosi 0,771, a korigirani koeficijenti Crnobach alfa su u rasponu 0,728-0,759 što ukazuje na to da sve čestice pridonose ukupnoj ocjeni konstrukta i potvrđuju konstruktnu valjanost ovog segmenta mjernog modela. Za čestice D1 $(p=0,008)$ i D10 $(p=0,006)$ primjećuju se statistički značajne razlike u raspodjelama ocjena za dvije predmetne aplikacije.
Tablica 6. Prosječna ocjena za "Ergonomsku kategoriju"

Table 6. Average rating for "Ergonomic category"

\begin{tabular}{|c|c|c|c|c|}
\hline Čest. & Sinarm & WebZNR & $p$ & Kor. C. $\alpha$ \\
\hline \multirow[t]{2}{*}{ D1 } & \multicolumn{4}{|c|}{$\begin{array}{l}\text { Korisniku je omogućen odabir boja pojedinih } \\
\text { dijelova zaslonskog prikaza kao što su npr. } \\
\text { boja pozadine pojedinog prozora, boja i } \\
\text { veličina slova te boja podloga u izbornicima, } \\
\text { boja i veličina natpisa upozorenja i sl. }\end{array}$} \\
\hline & 3,57 & 2,41 & 0,008* & 0,728 \\
\hline \multirow[t]{2}{*}{ D2 } & \multicolumn{4}{|c|}{$\begin{array}{c}\text { Korisniku je omogućen odabir zvučnih } \\
\text { upozorenja koja prate pojavu vizualnih } \\
\text { upozorenja }\end{array}$} \\
\hline & 3,00 & 2,30 & 0,134 & 0,749 \\
\hline \multirow[t]{2}{*}{ D3 } & \multicolumn{4}{|c|}{$\begin{array}{c}\text { Korisničko sučelje programa je vrlo pregledno } \\
\text { i razumljivo, a odabir pojedinih opcija } \\
\text { intuitivan i jednostavan }\end{array}$} \\
\hline & 3,29 & 3,48 & 0,634 & 0,759 \\
\hline \multirow[t]{2}{*}{ D4 } & \multicolumn{4}{|c|}{$\begin{array}{l}\text { Rukovanje programom je vrlo jednostavno i } \\
\text { vrlo brzo se uči }\end{array}$} \\
\hline & 3,86 & 3,74 & 0,979 & 0,758 \\
\hline \multirow[t]{2}{*}{ D5 } & \multicolumn{4}{|c|}{$\begin{array}{l}\text { Eventualne pogreške počinjene prilikom unosa } \\
\text { podataka lako se i jednostavno ispravljaju }\end{array}$} \\
\hline & 3,86 & 3,74 & 0,557 & 0,744 \\
\hline \multirow[t]{2}{*}{ D6 } & \multicolumn{4}{|c|}{$\begin{array}{c}\text { Program omogućava korisniku kreiranje i } \\
\text { prikaz vlastitih podsjetnika i smjernica za } \\
\text { pomoć }\end{array}$} \\
\hline & 3,29 & 2,55 & 0,112 & 0,749 \\
\hline \multirow[t]{2}{*}{ D7 } & \multicolumn{4}{|c|}{$\begin{array}{l}\text { Program ima ugrađen dobro razrađen i uvijek } \\
\text { dostupan sustav kontekstualne pomoći koji } \\
\text { se može pozvati npr. pritiskom na tipku F1, } \\
\text { pritiskom desne tipke miša i sl. }\end{array}$} \\
\hline & 3,29 & 2,63 & 0,105 & 0,757 \\
\hline \multirow[t]{2}{*}{ D8 } & \multicolumn{4}{|c|}{$\begin{array}{c}\text { Proizvođač programske podrške osigurao je i } \\
\text { isporučio korisniku detaljne korisničke upute } \\
\text { u tiskanom i/ili elektroničkom obliku }\end{array}$} \\
\hline & 3,57 & 3,51 & 0,692 & 0,756 \\
\hline \multirow[t]{2}{*}{ D9 } & \multicolumn{4}{|c|}{$\begin{array}{c}\text { Proizvođač (isporučitelj) programske podrške } \\
\text { osigurao je korisnicima službu telefonske } \\
\text { pomoći (helpdesk) uvijek dostupnu tijekom } \\
\text { radnog vremena }\end{array}$} \\
\hline & 3,00 & 3,56 & 0,055 & 0,756 \\
\hline \multirow[t]{2}{*}{ D10 } & \multicolumn{4}{|c|}{$\begin{array}{c}\text { Primjena programa znatno olakšava, ubrzava i } \\
\text { unaprjeđuje rad }\end{array}$} \\
\hline & 4,86 & 4,07 & 0,006* & 0,755 \\
\hline
\end{tabular}

*statistički značajna razlika 
Tablica 7 prikazuje ukupne prosječne ocjene za pojedine aplikacije i pojedine kategorije.

Tablica 7. Ukupna prosječna ocjena za aplikacije i kategorije

Table 7. Overall average score for applications and categories

\begin{tabular}{||c|c|c|c|c||}
\hline Kategorije & WebZNR & Sinarm & Cron. $\boldsymbol{\alpha}$ & $\begin{array}{c}\text { Prosjek za } \\
\text { kategoriju }\end{array}$ \\
\hline $\begin{array}{c}\text { A-Domenska } \\
\text { kategorija - } \\
\text { kakvoća }\end{array}$ & 2,76 & 3,03 & 0,907 & 2,90 \\
\hline $\begin{array}{c}\text { B-Domenska } \\
\text { kategorija - } \\
\text { utilizacija }\end{array}$ & 2,41 & 2,02 & 0,904 & 2,22 \\
\hline $\begin{array}{c}\text { C-Sigurnost i } \\
\text { aktualnost } \\
\text { podataka }\end{array}$ & 3,40 & 3,14 & 0,744 & 3,27 \\
\hline $\begin{array}{c}\text { D-Ergonomska } \\
\text { kategorija }\end{array}$ & 3,19 & 3,55 & 0,771 & 3,37 \\
\hline $\begin{array}{c}\text { Prosjek za } \\
\text { aplikaciju }\end{array}$ & 2,94 & 2,94 & \multicolumn{1}{|l||}{} \\
\hline
\end{tabular}

\section{RASPRAVA}

Analiza strukture zatečenog (tzv. prigodnog) uzorka ispitne populacije pokazala je da ovaj relativno mali uzorak većinom čine muškarci (79 \%). Najveći broj stručnjaka zaštite na radu unutar ovog uzorka zaposlen je u tvrtkama s velikim brojem zaposlenika (79 \%), a čak trećina ispitanika je u dobi iznad 50 godina. Najučestaliji način informiranja o mogućim programskim rješenjima su prodajni predstavnici aplikacija ili ovlaštene tvrtke koje obavljaju ispitivanje i osposobljavanja, dok je najmanja incidencija saznanja na stručnim skupovima i putem digitalnih medija. S oprezom bi se mogla uzeti indicija da bi razlog tome mogla biti činjenica slabe posjećenosti stručnih skupova, digitalna nepismenost ili čak nezainteresiranost stručnjaka ZNR za unapređenje, odnosno digitalizaciju poslova, a što svakako ne ide u korist struci.

U "Domenskoj kategoriji - kakvoća" mjereno je zadovoljstvo korisnika (time posredno i kvaliteta) pojedinim funkcionalnostima ugrađenim u programsko rješenje. Ovdje je kroz 16 pitanja ocijenjena kakvoća pojedinih funkcionalnosti, tj. modula koji su ključni prilikom vođenja poslova
ZNR. Prosječna ocjena ispitanika u ovoj kategoriji (Sinarm: 3,03, WebZNR: 2,76) je relativno niska odnosno označava osrednju primjenjivost programskih rješenja. Budući da su ocjene obje skupine ispitanika gotovo podjednake te nema statistički značajne razlike u odgovorima, može se zaključiti da je, bez obzira o kojem se programskom rješenju radi, cjelokupno zadovoljstvo kakvoćom osrednje, što znači da bi se u ovoj kategoriji oba programska rješenja mogla značajno unaprijediti.

Nadalje, polovina ispitanika ocijenila je da osposobljavanje radnika putem učenja na daljinu (eng. e-learning) uopće nije primjenjivo ili je neupotrebljivo, odnosno da je loše primijenjeno, a gotovo dvije trećine in je ocijenilo da rad s mobilnih uređaja uopće nije primjenjiv. Više od pola ispitanika izjasnilo se da je automatsko učitavanje zapisnika ovlaštenih tvrtki, koje obavljaju ispitivanja ili održavanja, u aplikaciju - neupotrebljivo. Statistički značajna razlika raspodjela ocjena postoji između ispitanika koji koriste ocjenjivana programska rješenja za pitanje A13 - Praćenje i planiranje troškova (za sva ispitivanja i liječničke preglede), gdje je p=0,04. S obzirom da je prosječna ocjena ispitanika koji koriste programsko rješenje Sinarm za pitanje $A 13=3,28$, a ispitanika koji koriste programsko rješenje WebZNR $\mathrm{A} 13=2,25$, može se reći da su ispitanici koji koriste programsko rješenje Sinarm zadovoljniji za parametar kvalitete koji se ispituje pod pitanjem A13. Na temelju prethodno prikazanih ocjena u ovoj kategoriji te na temelju prosječne ocjene za ukupnu kategoriju može se zaključiti da postoji određeni prostor za funkcionalno unapređivanje programskih rješenja.

U "Domenskoj kategoriji - utilizacija" tj. stupnju korištenja funkcionalnosti aplikacija, u praksi je kroz 17 pitanja ocijenjen stupanj korištenja pojedinih funkcionalnosti i aplikacije u cjelini. Prosječna ocjena ispitanika u ovoj kategoriji (Sinarm: 2,02, WebZNR: 2,41) također je relativno niska odnosno označava osrednju korištenost tih funkcionalnosti u praksi. Budući da su ocjene obje skupine ispitanika podjednake te nema statistički značajne razlike u odgovorima, može se zaključiti da je, bez obzira o kojem se programskom rješenju radi, cjelokupno zadovoljstvo stupnjem korištenja vrlo nisko, što znači da bi se i u ovoj 
kategoriji oba programska rješenja mogla i trebala značajno unaprijediti. Zanimljivo je da se upravo u procjeni pojedinih modula programskih rješenja, u 12 od 17 pitanja više od $70 \%$ pa čak i do maksimalno $90 \%$ ispitanika izjasnilo da se uopće ne koristi postojećim programom. Činjenica da se ipak neki ispitanici nekoliko puta tjedno, pa čak i svakodnevno koriste određenim modulima u ovoj kategoriji, govori da nije problem u aplikaciji (koja nudi ove mogućnosti) već u korisnicima koji ne koriste mogućnosti te iste aplikacije. Upravo iz ovog razloga otvara se pitanje adekvatne edukacije korisnika i poticanje na potpuno korištenje mogućnosti danog programskog rješenja.

U kategoriji "Sigurnost i aktualnost podataka" kroz šest pitanja ocijenjena je sigurnost i aktualnost (pravovremeno obnavljanje) podataka, odnosno propisanih nomenklatura. Prosječna ocjena korisnika u ovoj kategoriji je slična prethodno opisanim kategorijama (Sinarm: 3,14, WebZNR: 3,40 ). Budući da su ocjene obje skupine ispitanika gotovo podjednake te nema statistički značajne razlike u odgovorima, može se zaključiti da je, bez obzira o kojem se programskom rješenju radi, zadovoljstvo ispitanika sigurnošću i aktualnošću podataka srednje, što znači da bi i u ovoj kategoriji oba programska rješenja trebalo unaprijediti. S obzirom da su raspodjele ocjena za pitanje: "C4 - Na koji način se u vaše programsko rješenje unose i ažuriraju matični podaci (o djelatnicima i ustroju tvrtke, odnosno sinkronizacija s glavnim IS-om tvrtke)?", statistički značajne $(p=0,003)$ i prosječne ocjene iznose za Sinarm $=2,43$, a za WebZNR=3,52, može se zaključiti da su ispitanici koji koriste programsko rješenje WebZNR zadovoljniji pokazateljem koji se ispituje pod C4. Iz odgovora koji su dani u ovoj kategoriji može se zaključiti da su ispitanici dobro upoznati s mogućnostima koje im nudi aplikacija, a preko $80 \%$ ispitanika izjasnilo se da su programska rješenja pouzdana.

U "Ergonomskoj kategoriji" kroz 10 pitanja ocijenjeno je zadovoljstvo primjenom pojedinih ergonomskih svojstava kao npr. ocjena općih i tehničkih svojstava programske podrške, uključenje korisnika u proces razvoja programske opreme, motiviranost za korištenje programa, udio rada s opremom u odnosu na radno vrijeme, učestalost korištenja, kompleksnost posluživanja, vrijeme odziva sustava, pouzdanost i robusnost opreme. Prosječna ocjena korisnika u ovoj kategoriji je nešto viša od ostalih kategorija (Sinarm: 3,55, WebZNR: 3,19) te je ovo najbolje ocijenjena kategorija. Budući da su ocjene obje skupine ispitanika podjednake i nema statistički značajne razlike u odgovorima, može se zaključiti da je bez obzira o kojem se programskom rješenju radi, cjelokupno zadovoljstvo ergonomijom osrednje te da bi se i u ovoj kategoriji oba programska rješenja morala unaprijediti. $U$ ovoj kategoriji nameće se zaključak da više od $90 \%$ ispitanika ima pozitivno stajalište prema ergonomskim unapređenjima kroz primjenu pojedinih programskih mogućnosti koje im znatno olakšavaju rad. U kategoriji postoji statistički značajna razlika u raspodjeli ocjena između ispitanika koji koriste programsko rješenje Sinarm i ispitanika koji koriste programsko rješenje WebZNR, s obzirom na pitanje "D1 - Korisniku je omogućen odabir boja pojedinih dijelova zaslonskog prikaza kao što su npr. boja pozadine pojedinog prozora, boja i veličina slova te boja podloga u izbornicima, boja i veličina natpisa upozorenja i sl." ( $p=0,008)$ i pitanje "D10 - Primjena programa znatno olakšava, ubrzava i unaprjeđuje rad" $(p=0,006)$. S obzirom da prosječna ocjena za pitanje D1 za programsko rješenje Sinarm iznosi 3,57, a ispitanika koji koriste WebZNR iznosi 2,41 , može se reći da programsko rješenje Sinarm korisnicima nudi više opcija koje se ocjenjuju pod D1. Prosječna ocjena ispitanika za pitanje D10 za programsko rješenje Sinarm iznosi 4,86, a za Web ZNR iznosi 4,07. Može se reći da programsko rješenje Sinarm ispitanicima znatno olakšava, ubrzava i unapređuje rad u odnosu na ispitanike koji su korisnici WebZNR programskog rješenja.

Iz vrijednosti ukupnih prosječnih ocjena po pojedinoj aplikaciji i pojedinoj kategoriji (Tablica 7) vidi se da su ukupne prosječne ocjene u malom rasponu od srednjih prema nižim što nedvojbeno upućuje na činjenicu da za obje aplikacije postoji velik prostor za daljnji napredak i razvoj funkcionalnosti. Na prvi pogled iznenađuje činjenica da su ukupne ocjene za oba programska rješenja jednake $(2,94)$. No, treba imati u vidu da se radi o dva suvremena rješenja izrađena u tehnologiji računalstva u oblaku (engl. cloud computing) koja su na tržištu dobro prezentirana, nastoje sve intenzivnije pratiti zahtjeve stručnjaka ZNR na tržištu, a nastoje na temeljima zdrave kompeticije međusobno ujednačavati i unapređivati funkcionalnosti svojih proizvoda. 
Pored prethodno navedenih i opisanih statističkih testova, autori su proveli i testiranje raspodjele manifestnih varijabli ovisno o nezavisnim varijablama "spol" i "dobna skupina". Za varijablu "spol" primijenjen je također Mann-Whitney U test, koji nije pokazao statistički značajne razlike u raspodjeli ocjena u ovisnosti o spolu, odnosno o mogućem različitom senzibilitetu pri ocjenjivanju između pristupnica i pristupnika. Za testiranje raspodjela u ovisnosti o varijabli "dobna skupina" (tri dobne skupine), korišten je KruskalWallis $\mathrm{H}$ test (koristi se za više od dvije skupine vrijednosti). Ovaj test pokazao je statistički značajne raspodjele ocjena za čestice, odnosno pitanja: B1 ( $p=0,001), B 2(p=0,008), B 6(p=0,017)$, C5 $(p=0,010), D 1(p=0,029)$ i D4 $(p=0,025)$. No, kako se radi o relativno maloj ispitnoj populaciji u kojoj dominira dobna skupina 31-50 godina starosti (53\%), a za njom slijedi dobna skupina 51-65 godina starosti (32\%), pretpostavlja se da postoji različita percepcija i shvaćanje postavljenih pitanja. U svakom slučaju ovo se uzima kao pokazatelj o kojem treba voditi računa pri pripremi i provođenju ponovljenog ispitivanja (mjerenja), koje bi svakako trebalo ubuduće provesti na puno reprezentativnijem uzorku ispitanika i ocjenjivanih programskih rješenja.

\section{ZAKLJUČAK}

Nedvojbeno je da je računalna podrška danas preduvjet kvalitetnom upravljanju vođenja evidencija ZNR. Osim uvođenja programskih rješenja po tvrtkama i ustanovama, predviđena je i izgradnja informacijsko-komunikacijske infrastrukture na razini cijele RH koja će prikupljati i objedinjavati sve bitne podatke o stručnjacima, tvrtkama, kontrolnim kućama, djelatnicima i događajima te na temelju pravovremenih podataka i informacija omogućiti napredno predviđanje i smanjivanje rizika na radnom mjestu, unapređenje zdravlja radnika i smanjivanje ukupnih troškova proizvodnje. Testirane aplikacije primjer su klijentskih programskih rješenja koja će prikupljati podatke u tvrtkama, na radnim mjestima i radilištima te pripremati podatke za popunjavanje budućeg središnjeg nacionalnog informacijskog sustava ZNR. Iz ovog razloga predmetna programska rješenja morat će imati ujednačene i kontrolirane funkcionalnosti čije će funkcionalno stanje i kvalitetu biti potrebno periodički procjenjivati, odnosno mjeriti. Provedeno istraživanje i prikazani okvirni mjerni model za mjerenje funkcionalne kvalitete svakako je prvi projekt ovog tipa u području ZNR u RH. Štoviše, prethodna pretraživanja dostupnih mrežnih sadržaja nisu pokazala postojanja sličnih projekata na europskoj pa niti na svjetskoj razini. Na području $\mathrm{RH}$ nalaze se do sada dva ozbiljnija, ali metodološki drugačija istraživanja povezana s mjerenjem kvalitete programske podrške u području poslovnih (Fertalj et al., 2002.) i zdravstvenih (Kralj et al., 2015.) informacijskih sustava. Ovo je prvi pokušaj oblikovanja okvirnog mjernog modela i metodologije te će ih svakako u predstojećem razdoblju biti potrebno dalje verificirati i unapređivati.

Za kvalitetnije i relevantnije rezultate osnovni preduvjet je veći i reprezentativniji uzorak ispitne populacije, a preduvjet za to su educirani i motivirani stručnjaci ZNR koji svakodnevno u radu koriste ova programska rješenja. Aktualna regulativa zaštite osobnih podataka uvelike usporava i onemogućava prikupljanje adresa i podataka za dostavu poziva i motivacijskih pisama potencijalnim pristupnicima. Postojanje sindikalnog i/ili strukovnog udruživanja u području ZNR uvelike bi olakšalo ne samo organizaciju ovakvih testiranja, već i dostavu promotivnog i edukacijskog materijala o važnosti i načinu provođenja ovakvih istraživanja. Na ovaj način uvelike bi se olakšalo i dobivanje privola za korištenje pristupnih osobnih podataka.

Sagledaju li se ukupni rezultati i podaci o cjelokupnom testnom uzorku, dobiva se dojam da još uvijek veliki broj stručnjaka zaštite na radu koristi zastarjeli tip rada - papir i/ili Excel. Zaključak se nameće na temelju udjela ispitne populacije koja je odbačena, jer ne koristi niti jedno komercijalno dostupno rješenje na tržištu, ali i udjela onih koji koriste specijalizirane aplikacije, a paralelno prakticiraju i zastarjele metode vođenja evidencija. Znatan je i dio populacije koja koristi specijalizirana programska rješenja, ali u praksi koriste vrlo mali dio njihovih funkcionalnosti. Stoga se nameće potreba provođenja edukacije u više razina: o važnosti primjene informacijsko-komunikacijske tehnologije, mogućnostima korištenog programskog rješenja te o važnosti i načinima provođenja postupka vrednovanja kvalitete korištene programske podrške. 


\section{LITERATURA}

Cronbach, L. J., Gleser, G. C., Nanda, H., Rajaratnam, N.: The dependabillity of behavioral measurements: Theory of generalizabillity for scores and profiles, Wiley, New York, 1972.

Eterović. D., Kardum, G.: Biostatika za studente medicine - 5. izdanje, Medicinski fakultet Sveučilišta u Splitu, Split, 2010.

Fertalj, K. et al.: Komparativna analiza programske potpore informacijskim sustavima u $\mathrm{Hr}$ vatskoj, Fakultet elektrotehnike i računarstava, Zagreb, 2002., dostupno na: https://bib.irb.hr/ datoteka/483983.ERP-HR-11a.pdf, pristupljeno: 13.4.2020.

Grassi, M. et al.: Performance Copmparison of Likert and Binary Formats of SF-36 Version I. 6 Acros ECRHS II Adults Populations. Value in Health, 10, 2007, 6, 478-88. dostupno na: http:// public-files.prbb.org/publicacions/ 1 fecfc307eff-012a-a769-000c293b26d5.pdf, pristupljeno: 13.4.2020.

International Labour Organization: Data sources for Optimizing the Collection and Use of OSH data, 2017. dostupno na: https://www.ilo.org/ wcmsp5/groups/public/---ed_protect/---protrav/--safework/documents/publication/wcms_546703. pdf, pristupljeno: 1.6.2019.

Jajetić, T., Kralj, D.: Anketni upitnik, dostupno na: https://docs.google.com/forms/d/1dD-hUmLkIUH4CLUZ5jxzgD6t10yk68TL3N7y7P8nC7k/ edit, pristupljeno: 15.1.2020.
Kline, R.B.: Principles and Practic of Structural Equation Modeling, The Guilford Press, New York, 1998.

Kralj, D. et al.: Development of the quality assessment model of EHR software in family medicine practices: research based on user satisfaction, Journal of Innovation in Health Informatics, 22, 2015., 3, 340-58.

Linija koda d.o.o.: Programsko rješenje "WebZNR", dostupno na: https://www.zastitanaradu. hr/, pristupljeno: 13.4.2020.

Pallant, J.: SPSS Survival Manual, McGraw Hill Inc., New York, 2007., dostupno na: https://epdf. pub/spss-survival-manual-a-step-by-step-guideto-data-analysis-using-the-spss-progra.html, pristupljeno: 13.4.2020.

Reynaldo, J., Santos. A.: Cronbach's Alpha: A Tool for Assessing the Reliability of Scales. Journal of Extension, 37, April 1999., 2, 1-4. dostupno na: https://www.joe.org/joe/1999april/tt3.php, pristupljeno: 13.4.2020.

Urbina, S.: Eseential of Psychological Testing, John Wiley \& Sons, Hoboken, New Jersey, 2004.

Vučinić, J.: Pravno reguliranje zaštite na radu, Veleučilište u Karlovcu, Karlovac, 2008.

web IT d.o.o.: Programsko rješenje "Sinarm", dostupno na: http://www.sinarm.net/, pristupljeno: 13.4 .2020 .

Zar, J.H.: Biostatistical Analysis - 5th ed., Pearson Prentice Hall, New Jersey, 2010.

Zakon o zaštiti na radu, N.N., br. 71/14., 118/14., 94/18. i 96/18. 


\section{FRAMEWORK MODEL FOR ASSESSMENT OF THE QUALITY OF SOFTWARE} SUPPORT IN THE FIELD OF SAFETY AT WORK

SUMMARY: Computer support for keeping records of safety at work has become today a necessity and a prerequisite for quality management of this important and very complex issue. Accordingly, an increasing number of software solutions appear on the market to support the keeping of occupational safety records. The functionality of these programs and record formats in the Republic of Croatia is not fully defined nor is there a formal certification process. In order to determine the quality of these software solutions based on experience and customer satisfaction, we designed a framework assessment model organized in five measurement categories that include content assessment, functional quality, utilization, data security and actuality, and ergonomics of the software itself. The research was conducted online via an electronic questionnaire. Data analysis, reliability and validity of the questionnaire were performed. A relevant number of respondents was collected for two software solutions. In both cases, the overall quality assessments do not differ significantly, but indicate a very large area for further improvement of functional quality.

Key words: safety at work, computer support, assessment model, functional quality, software ergonomics

Original scientific paper Received: 2020-09-16

Accepted: 2021-03-15 